\title{
Using fish assemblage to identify success criteria for seagrass habitat restoration
}

\author{
L. Scapin, M. Zucchetta, C. Facca, A. Sfriso, and P. Franzoi \\ CEMAS - Centre for Estuarine and coastal MArine Sciences c.o. DAIS, Department of Environmental \\ Sciences, Informatics and Statistics, Università Ca’ Foscari Venezia, Via Torino 155, 30170 Venice, Italy
}

Correspondence to: L. Scapin (luca.scapin@stud.unive.it)

Received: 15 October 2015 - Revised: 28 December 2015 - Accepted: 11 January 2016 - Published: 4 February 2016

\begin{abstract}
A fish-based multimetric index was applied to assess the ecological status of fish fauna in both natural and newly restored seagrass meadows in the Venice lagoon (northern Adriatic Sea, Italy), using natural habitats as reference sites. Fish assemblages were then compared, and community attributes of recreated and natural habitats were evaluated. Ecological status resulted higher in natural meadows, and a multivariate analysis showed that an increase in the relative proportion of seagrass specialists at restored sites could represent an indicator of success of seagrass restoration.
\end{abstract}

\section{Introduction}

Seagrass meadows provide important ecological functions, such as sediment stabilisation, $\mathrm{CO}_{2}$ absorption, and habitat for fish assemblages. In the Venice lagoon (northern Adriatic Sea, Italy), their extent has been greatly reduced in the last decades due to multiple human activities (Sfriso and Facca, 2007). In the northern sub-basin of the lagoon, an extensive habitat recreation scheme started in 2014 aiming at restoring seagrass meadows. Cymodocea nodosa (Ucria) Ascherson, 1870; Zostera marina Linnaeus, 1753; Zostera noltei Hornemann, 1832; and Ruppia cirrhosa (Petagna) Grande, 1918, sods and rhizomes were transplanted during spring 2014 at 17 sites, each species accounting for different proportion at each site according to local environmental conditions. This is expected to enhance the ecological status (sensu Directive 2000/60/EC - Water Framework Directive; WFD) of faunal communities of the area, including fish assemblages. The aim of this work was to identify the characteristics of the fish assemblage associated with seagrass meadows in the Venice lagoon. A set of metrics based on these characteristics was tested as potential indicators, to be used to evaluate the success of the scheme after its completion (expected in 2018), in terms of both enhancement of ecological status and habitat functionality for fish.

\section{Methods}

The study was carried out in the Venice lagoon. Fish fauna was sampled during spring and autumn 2014 at eight of the seagrass restoration sites. In addition, data from nine natural seagrass meadow sites were collected during the same periods and used as a reference. Fish were collected with a beach seine net following the methodology of Franco et al. (2006). Fish biomass $(g)$ was standardised by area $\left(100 \mathrm{~m}^{2}\right)$. Habitat typology at both reference and restoration sites was identified by visual census and classified according to the presence of either bare substratum or natural seagrass coverage dominated by $C$. nodosa, Z. marina, Z. noltei, or R. cirrhosa.

The habitat fish bioindicator index (HFBI-Ve; Zucchetta et al., 2016), a multimetric index composed of four metrics summarising functional attributes of fish assemblages (Table 1), was applied to assess the ecological status (expressed as "high", "good", "moderate", "poor", or "bad") of fish assemblages at both reference and restoration sites.

A preliminary analysis revealed that reference and restoration sites were not comparable to each other in terms of habitat structure, since seagrass meadows were still absent at most of the transplanted sites during the sampling period. A two-way PERMANOVA was employed to test the effect of seasonality and habitat typology on community structure of both reference and restoration sites, using the Bray-Curtis similarity index on the fourth-root-transformed biomass den- 
Table 1. Description of the four metrics selected for the development of the habitat fish bioindicator index for the Venice lagoon.

\begin{tabular}{ll}
\hline Metric & Description \\
\hline Total density of biomass & Total biomass in the sample $\left(g \times 100 \mathrm{~m}^{-2}\right)$ \\
\hline Number of lagoon resident species & $\begin{array}{l}\text { Number of species with populations spending their } \\
\text { entire life cycle within the lagoon }\end{array}$ \\
\hline Average individual weight of benthivorous species & $\begin{array}{l}\text { Biomass / abundance ratio of species feeding on epi- } \\
\text { fauna and infauna }\end{array}$ \\
\hline $\begin{array}{l}\text { Margalef's richness index of hyperbenthivorous/ } \\
\text { zooplanktivorous/piscivorous species, calculated } \\
\text { on biomass }\end{array}$ & $\begin{array}{l}\text { Margalef's index calculated on biomass of species } \\
\text { feeding on hyperbenthos, zooplankton, and/or fish }\end{array}$ \\
\hline
\end{tabular}

Table 2. Description of candidate metrics for the evaluation of the success of seagrass restoration in the Venice lagoon.

\begin{tabular}{|c|c|c|c|}
\hline Category & Label & Metric & Description \\
\hline \multirow[t]{2}{*}{$\begin{array}{l}\text { Metrics based on the } \\
\text { whole assemblage }\end{array}$} & M1 & Total density of biomass & $\begin{array}{l}\text { Sum of biomass density of all } \\
\text { species caught }\left(g \times 100 \mathrm{~m}^{-2}\right)\end{array}$ \\
\hline & M2 & Total number of species & - \\
\hline \multirow[t]{2}{*}{$\begin{array}{l}\text { Metrics based on indi- } \\
\text { cator species: Nerophis } \\
\text { ophidion, Salaria pavo, } \\
\text { Syngnathus typhle, Zos- } \\
\text { terisessor ophiocephalus }\end{array}$} & M3 & $\begin{array}{l}\text { Proportion of biomass of } \\
\text { indicator species }\end{array}$ & $\begin{array}{l}\text { Ratio between biomass density } \\
\text { of indicator species and total } \\
\text { biomass density. It ranges be- } \\
\text { tween } 0 \text { (indicator species ac- } \\
\text { count for } 0 \% \text { of total biomass } \\
\text { density) and } 1 \text { (indicator species } \\
\text { account for } 100 \% \text { of biomass } \\
\text { density) }\end{array}$ \\
\hline & M4 & $\begin{array}{l}\text { Proportion of indicator } \\
\text { species }\end{array}$ & $\begin{array}{l}\text { Ratio between number of indica- } \\
\text { tor species and total number of } \\
\text { species. It ranges between } 0 \text { (in- } \\
\text { dicator species account for } 0 \% \\
\text { of total number of species) and } \\
1 \text { (indicator species account for } \\
100 \% \text { of total number of species) }\end{array}$ \\
\hline
\end{tabular}

sity matrix (999 permutations). Multivariate results were visualised with non-metric multidimensional scaling (nMDS). All resident species occurring more than once in the samples, whose scores were closer to the reference sites than to the restoration sites in the ordination plot (hence best explaining the distribution pattern of reference sites in nMDS), were selected as indicator species. A set of synthetic metrics was then computed, considering both the whole community and indicator species (Table 2). The effects of season and habitat typology were studied on each metric separately by means of a univariate PERMANOVA, using Euclidean distance with 999 permutations.

\section{Results}

Overall, a higher ecological status of fish assemblages was assessed by the HFBI-Ve at reference sites compared with restoration sites. Fish assemblages were significantly differ- ent between sampling seasons $(p$ value $<0.05)$ and natural habitat typologies ( $p$ value $<0.01$ ). Lagoon resident species accounted for a greater proportion of total biomass at both reference and restoration sites, with species associated with unvegetated habitats being recorded with higher biomasses at restoration sites. In turn, reference seagrass meadows were characterised by higher biomasses of residents such as Nerophis ophidion Linnaeus, Salaria pavo Risso, Syngnathus typhle Linnaeus, and Zosterisessor ophiocephalus Pallas (Fig. 1), these being selected as indicator species.

No significant effect of season and habitat typology was found on either total density of biomass (M1, Table 2) or total number of species in the fish assemblage (M2, Table 2). Conversely, the proportion of indicator species, in terms of both biomass density (M3, Table 2) and species number (M4, Table 2), showed significant differences among seasons ( $p$ value $<0.05)$ and habitat typologies $(p$ value $<0.001)$. In particular, higher values of these metrics were registered in 


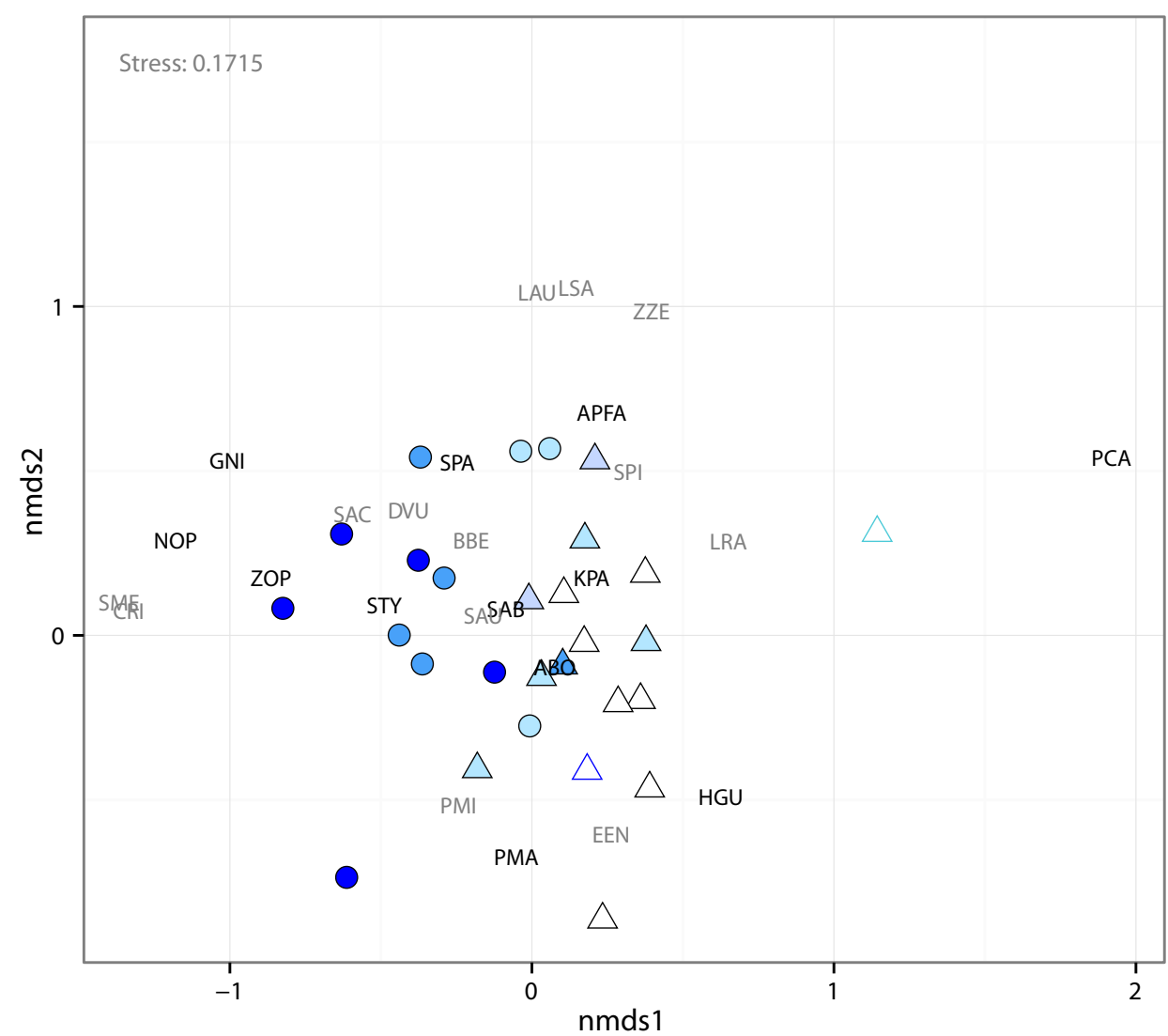

Site typology

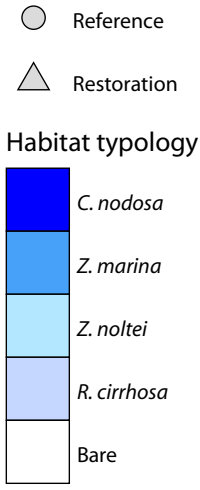

Seagrass species transplanted

$\triangle$ C. nodosa, Z. marina, Z. noltei

$\triangle$ Z. marina, Z. noltei

$\triangle$ Z. noltei, R. cirrhosa

Species

$\mathrm{ABO}$ Lagoon residents

BBE Marine migrants and stragglers

Figure 1. nMDS ordination of fish assemblage at seagrass restoration sites and reference sites. Observations made in each habitat typology (seagrass habitat dominated by C. nodosa, Z. marina, Z. noltei, R. cirrhosa, and bare substratum) and seagrass species used in transplantations are also shown. Fish species (either lagoon residents or marine migrants and stragglers) are labelled as follows: ABO: Atherina boyeri Risso; APFA: Aphanius fasciatus Valenciennes; BBE: Belone belone Linnaeus; CRI: Callionymus risso Lesueur; DVU: Diplodus vulgaris Geoffroy Saint-Hilaire; EEN: Engraulis encrasicolus Linnaeus; GNI: Gobius niger Linnaeus; HGU: Hippocampus guttulatus Cuvier; KPA: Knipowitschia panizzae Verga; LAU: Liza aurata Risso; LRA: L. ramada Risso; LSA: L. saliens Risso; NOP: Nerophis ophidion; PCA: Pomatoschistus canestrinii Ninni; PMA: P. marmoratus Risso; PMI: P. minutus Pallas; SAB: Syngnathus abaster Risso; SAC: S. acus Linnaeus; SAU: Sparus aurata Linnaeus; SME: Symphodus melops Linnaeus; SPA: Salaria pavo; SPI: Sardina pilchardus Walbaum; STY: Syngnathus typhle; ZOP: Zosterisessor ophiocephalus; ZZE: Zebrus zebrus Risso.

autumn and in meadows dominated by either $C$. nodosa or $Z$. marina (Fig. 2).

\section{Discussion and conclusions}

Success criteria to assess restoration of fish assemblages associated with seagrass meadows were identified in this study, using data from the first year of seagrass restoration in the northern Venice lagoon. Among metrics constituting the habitat fish bioindicator index, indicators based on biomass of benthivorous and piscivorous lagoon resident species are included. The index application suggests that restoring seagrass meadows in the northern Venice lagoon could enhance the status of fish fauna in this area, for example by providing breeding ground for the grass goby Z. ophiocephalus (a hyperbenthivorous/piscivorous lagoon resident) and essential refuge and trophic habitat for pipefishes (family Syngnathi- dae; mostly benthivorous and piscivorous lagoon residents) (Franzoi et al., 2010; Malavasi et al., 2005, 2007). The values of indicators based on the seagrass specialists $N$. ophidion, S. typhle, and Z. ophiocephalus, as well as on S. pavo, are expected to increase together with the development of new seagrass habitat. However, different fish assemblages may colonise meadows restored with either the broad- and long-leaved species $C$. nodosa and Z. marina or the narrowand short-leaved $Z$. noltei and $R$. cirrhosa. Hence, different levels of success at the end of the project are expected among transplantation sites, in terms of restoration of fish communities. 

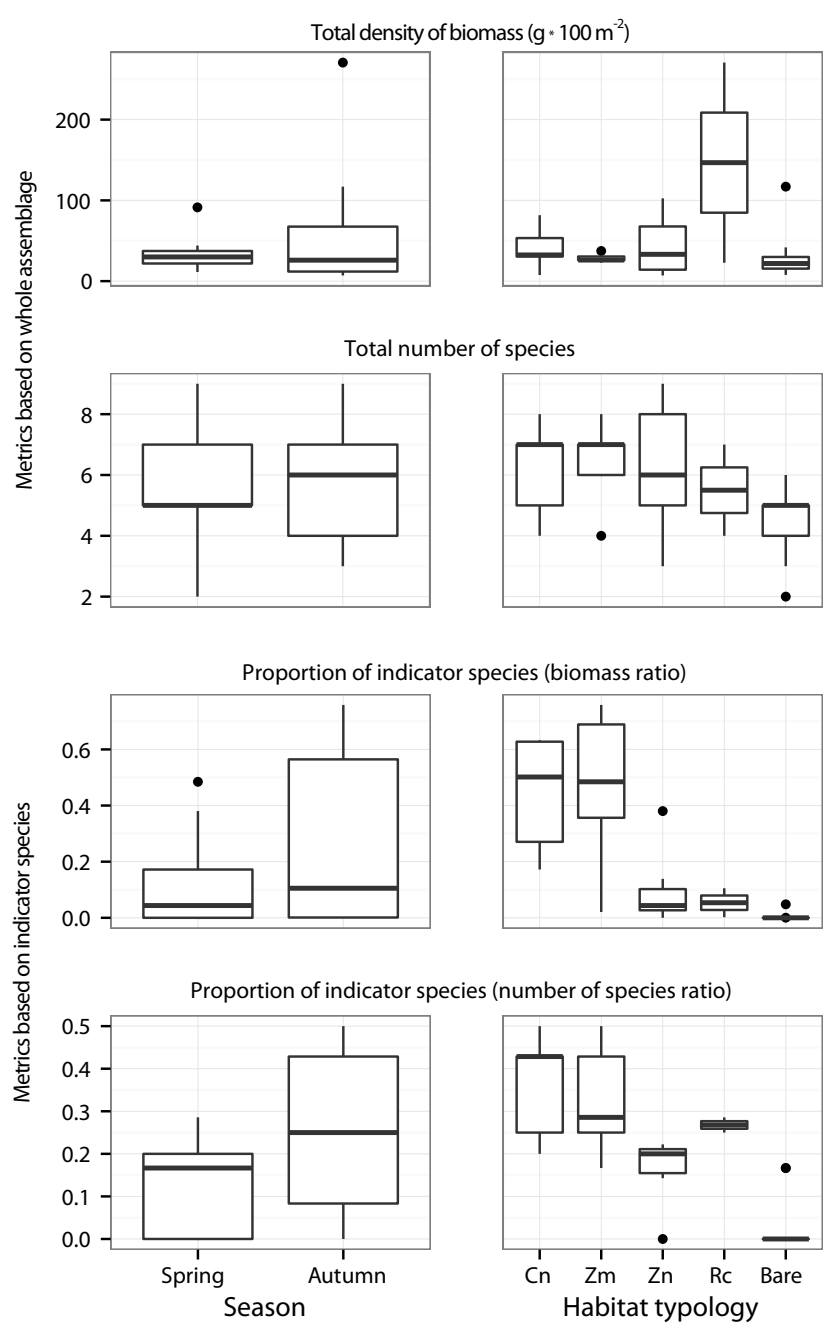

Figure 2. Distribution among seasons and habitat typologies of candidate metrics based on the whole fish assemblage and on indicator species. Habitat typologies are abbreviated as follows: $\mathrm{Cn}$ : Cymodocea nodosa; Zm: Zostera marina; $\mathrm{Zn:} \mathrm{Zostera} \mathrm{noltei;} \mathrm{Rc:}$ Ruppia cirrhosa.; Bare: bare substratum.

Acknowledgements. The LIFE12 NAT/IT/000331 - SEagrass RESTOration project (SeResto) started in 2014 aiming at restoring seagrass meadows in the northern Venice lagoon (northern Adriatic Sea, Italy). SeResto is funded by the European Union's LIFE+ financial instrument and contributes to the environmental recovery of a Natura 2000 site (SIC IT3250031 - Northern Venice Lagoon).

Edited by: J. Stadler

Reviewed by: two anonymous referees

\section{References}

Franco, A., Franzoi, P., Malavasi, S., Riccato, F., Torricelli, P., and Mainardi, D.: Use of shallow water habitats by fish assemblages in a Mediterranean coastal lagoon, Estuar. Coast. Shelf Sci., 66, 67-83, doi:10.1016/j.ecss.2005.07.020, 2006.

Franzoi, P., Franco, A., and Torricelli, P.: Fish assemblage diversity and dynamics in the Venice lagoon, Rend. Lincei, 21, 269-281, doi:10.1007/s12210-010-0079-z, 2010.

Malavasi, S., Franco, a., Fiorin, R., Franzoi, P., Torricelli, P., and Mainardi, D.: The shallow water gobiid assemblage of the Venice Lagoon: Abundance, seasonal variation and habitat partitioning, J. Fish Biol., 67(SUPPL. B), 146-165, doi:10.1111/j.00221112.2005.00919.x, 2005.

Malavasi, S., Franco, A., Riccato, F., Valerio, C., Torricelli, P., and Franzoi, P.: Habitat selection and spatial segregation in three pipefish species, Estuar. Coast. Shelf Sci., 75, 143-150, doi:10.1016/j.ecss.2007.02.022, 2007.

Sfriso, A. and Facca, C.: Distribution and production of macrophytes and phytoplankton in the lagoon of Venice: Comparison of actual and past situation, Hydrobiologia, 577, 71-85, doi:10.1007/s10750-006-0418-3, 2007.

Zucchetta, M., Franco, A., Scapin, L., Ciccotti, E., Torricelli, P., and Franzoi, P.: Uncertainty in developing fish-based multimetric indices, in preparation, 2016. 